\title{
DOE/SR/18048--T2
}

COVER SHEET

DOE Report Number

Title

Subtitle

Reporting Period

Personal Author

Contractor's Name

- Contractor's Address

Report Date

DOE Sponsorship and Contract Number
DOE/SR/18048-12

\section{STUDENT SCIENCE ENRICHMENT TRAINING PROGRAM}

Progress Report

JUNE 1, 1988 To MAY 31, 1989

Shingara S. Sandhu

Claflin College

Orangeburg, S.C. 29115

April 21, 1989

PREPARED FOR THE U.S. DEPARTMENT OF ENERGY UNDER GRANT DE-FG09-88SR 18048

\section{DISCLAIMER}

This report was prepared as an account of work sponsored by an agency of the United States Government. Neither the United States Government nor any agency thereof, nor any of their employees, makes any warranty, express or implied, or assumes any legal liability or responsibility for the accuracy, completeness, or usefulness of any information, apparatus, product, or process disclosed, or represents that its use would not infringe privately owned rights. Reference herein to any specific commercial product, process, or service by trade name, trademark, manufacturer, or otherwise does not necessarily constitute or imply its endorsement, recommendation, or favoring by the United States Government or any agency thereof. The views and opinions of authors expressed herein do not necessarily state or reflect those of the United States Government or any agency thereof. 


\section{DISCLAIMER}

Portions of this document may be illegible in electronic image products. Images are produced from the best available original document. 


\section{STUDENT SCIENCE ENRICHMENT TRAINING PROGRAM}

PROGRESS REPORT.

\section{Introduction}

Claflin College, a predominantly black undergraduate institution located in Orangeburg, South Carolina, has served the needs of rural communities for more than one hundred years. Claflin offers liberal arts and teacher preparation programs, and is fully accredited by the Southern Association of College and Secondary Schools.

The FTE (Full Time Enrollment) student enrollment during the first semester of 1987-88 was 850. According to the information obtained from the Office of Financial Aid, approximately 98 percent of the students received financial aid; on the average, a student was on 80 percent financial aid.

The church-related (United Methodist) school has experienced a significant expansion of its facilities in recent years. The Division of Natural Science and Mathematics is located in the James S. Thomas (JST) Science Center which was dedicated in 1976. It is a multimillion dollar modern building with good equipment and facilities.

The Division of Natural Sciences and Mathematics is composed of three departments: The Department of Biology, the Department of Chemistry, and the Department of Mathematics and Computer Science. The Department of Biology, Chemistry and Mathematics and Computer Science offer major and minor programs. The Department of Chemistry also offers a pre-medical curriculum. In addition to offering a major in mathematics, computer science, a composite major in mathematics and computer and a composit major in computer and business adminstration, the Department of Mathematics and Computer Science offers minors in Computer Science, Mathematics, and Physics. 


\section{Target Schools and Students}

As is shown in Table $I^{*}$ there is a progressive decline in the Science and Engineering Professions, chosen by the freshmen, entering colleges and universities. This is a nationwide trend and is not unique to Claflin College.

Table I,* Trends in science majors chosen by freshmen, nationwide

\section{PERCENTAGE OF ALL FRESHMEN}

Biological Sciences

Physical Sciences
1977

4.7

3.1
1985

3.4

2.4

Computer Science

1983

8.8
1984

6.1

Among students who complete degree programs in Sciences and Engineering, about one-half $(1 / 2)$ of the B.S. recipients, two-thirds $(2 / 3)$ of M.S. recipients and three-fourths (3/4) of Ph.D. recipients actually entered the science work force. The experts are already guessing, that by 1995 , there will be approximately 2 million more jobs than educated workers available for the new openings. They are also guessing, that blacks will continue to lose ground and the government will have to allow more immigrants in to make up the difference. If the present pattern of field selection continues and if employer demand does not abate, it is clear that 
the nation will face serious manpower supply shortage in technical fields over the next ten years.

Blacks and other minorities (Hispanics, American Indians) have a dismissal record when it comes to their freshmen year. Blacks form about $10 \%$ of the nation's workforce. However, they form only 2.7 percent of the national professional manpower. One thousand blacks recieved Ph.D. degrees in 1985 , out of which, only $30 \mathrm{Ph} . \mathrm{D}$. degrees were awarded in Science, Mathematics and Engineering. Majority of 30 doctorate receipients were in the field of Biology and Health. In South Carolina, minorities constitute 31.7 percent of the state population, but they form only 15.24 percent of the professional work force. The role of minorities in Science and Technology is very disappointing. A state, possibly, can not move speedily towards the new scientific horizons if a majority of its citizenry is incompetent to participate in the logic of decision making process relating to Science and Technology.

Today, black and other minorities constitute about twenty percent of the public high school's student bodies and by 2010 , the minorities will form over one-third of the total work force. One can go on quoting statistics to prove that the minorities are woefully under represented in the Science and Technology work force and a serious need exists to enhance their participation in these professions.

The Federal Government and several national companies have fully realized that there is going to be an acute shortage of technical manpower in the near future, consequently they have decided to exert their influence in increasing the role of minorities in the field of Science, Engineering and Mathematics. Historically Black Colleges and Universities wing of the Department of Energy at the Savannah River Operation Office was able to commit funds for the residential 1988 Summer, "Student Science 
Enrichment Training Program" which was held at the campus of Claflin College, Orangeburg, SC.

\section{PROJECT PROGRESS}

This project accepted thirty predominantly minority (Black) students. One student-dropped out on the second day of the program in order to take other required courses which would earn here sophomore status.

Twenty three of these students were high school juniors and seniors from rural South Carolina high schools, with limited science education programs. However, the project also provided an opportunity to the freshmen class of Claflin College. Six students from Claflin who opted to major in sciences chose to participate in this program. All student were black and came from small or medium sized towns in South Carolina.

This was a residential project. It was very helpful that the housing aid was given to the participants in this project, as the participants were recruited from rural areas where family incomes are very low and without room and board it would have been impossible to reach this group. Indeed, in the small and medium sized towns of South Carolina, making up for the loss of a student's summer earnings is a significant contribution by a family. It was a wise decision that the participants were compensated for room and board while they were on campus, enrolled in the summer project.

\section{Major Objectives of the Project}

In many of the rural high schools in South Carolina the science and computer educational opportunities are limited to simple classroom discussions with little in-depth exploration of subject matter.

Students from such schools graduate with preconceived notion about the difficult task of succeeding in science professions. In particular, the opportunities for laboratory experiences are non-existent in such schools. 
In recognition of the deficiencies in scientific knowledge and techniques, the following goals were adopted for this project:

A. Increase the pool of well-qualified college-entering minority students who will select to major in Physical and Engineering Sciences.

B. Develop and foster knowledge, understanding, and interest in science.

C. Offer Chemistry program which places emphasis upon laboratory experiences and some research participation.

D. Develop in minority students the belief that the Science career are exciting, challenging, and can be successfully pursued by minorities.

E. Arrange visits to scientific laboratories and other points of scientific interests for motivational purposes and generate scientific curiousity.

F. Assist students in making career choices by introducing them to a variety of information and experiences, including interaction with scientists, guest speakers and role models.

G. Motivate the participants to go back to their high schools and work hard to prepare themselves so that they will be able to pursue science careers in college.

H. Encourage and motivated participants to take national college entrance (SAT etc.) tests and have the appropiate college faculty to guide the students in that direction.

\section{Project Description}

The project for Student Science Enrichment Training Program (SSETP) was planned for minorities and disadvantage students who were (1) Rising Juniors (2) Rising Seniors and (3) Freshmen Class at Claflin College (1987-88 Freshmen Class). As soon as it was realize that the project will be funded by the HBCU/DOE, the project director in consulation with the various college admininstrators designed a brochure for the SSETP. The brochure was printed (see Enclosure 1). A list of all high schools, located in the State of South Carolina, was procured from the Office of the Admissions and Records. Five copies of the brochure which also included 
application blanks, was mailed to the chairman, Department of Science of each high school in the state. Copies of the brochure were also distributed to every freshmen at Claflin College. Additionally each freshmen orientation instructor at Claflin College was requested to talk to the students about the availability of SSETP during 1988 summer for such individuals who may be interested in science careers. The students who were identified by their teachers or guiding counselors or academic advisors, as capable of pursuing careers in Physcial Sciences and Engineering were encouraged to apply for SSETP.

In response to our approach, the project received 55 applications which were placed into following catagories (a) applicants from freshmen class at Claflin College (There were seven applicants) (b) applicants who expressed interest in choosing Claflin College for their undergraduate studies ( There were 14 such applicants) (c) applicants who were ready to go into Science careers, but their choice of undergraduate studies was not Claflin (d) the applicants who were not interested in science careers. The applicants in this catogory (d) were not considered for acceptance into SSETP. The project director interviewed, by telephone each of the remaining applicants to determine the firmness of their interest in Science, Engineering and Mathematics. All applicants from Claflin College were accepted into the program as they met several requirements, including one of increasing the student enrollment in the Division of Science and Mathematics and Computer Science. The applicants in the categories B and $\mathrm{C}$ were separetely graded based on the telephone interviews and their academic performance. Twenty five applicants out of these two categories were selected. All the selected applicants were informed through a letter. They were asked either to accept the offer by checking "Yes" or refuse the offer by checking "No" (see enclosure 2). Two applicants checked (No) and 
several of them did not care to respond. Consequently a subsidiary list of applicants who were on the waiting list was produced. The applicants in this group were made the similar offer as mentioned above. By June 13, 1988 we had thirty applicants (see enclosure 3) who committed to join the program for 1988 Summer. One out of thirty participants dropped out on the second day of initiation of the program as she wanted to take some required courses which she failed in spring semester of 1988 . She required these courses to earn sophomore status at Claflin College.

The students were housed in the college dormitories. The female students, numbering twice than the male participants, were accomodated in Asbury Hall, two per room on the ground floor. The male students were accomodated in High Rise dorm, three to a room. The project director and some other SSETP staff members were in the dorms to facilitate their moving into the assigned spaces.

The Student Science Enrichment Training Program (SSETP) ran concurrently with the college's summer school of 1988. The SSETP commenced on June 13 and ended on July 22,1988 . The students reported to the Science building on the morning of June 13, 1988. The participants were enrolled in Chemistry 121 (Gen. Chem) and Computer Science 200 (Computer concepts) for a total of 7 Semester Hours (SH). They were divided into two groups of 15 each. Consequently, there were two sections (A\&B) for Chem 121 and two sections for Computer Science course. One group of fifteen students took Computer Science and the other took Chemistry. The group rotated with each other so that each student was exposed to chemistry and computer operations and its applications in solving chemical problems. Chemistry academic programs, assisted by computer simulations and computer assisted instructions (CIA) to make learning of chemistry fun, were offered during six weeks of the program. 
Each student was aided to learn adequate fundamentals of computer handling and operations which were applied to the learning of Chemistry and en-hancement of computer expertise.

The students were involved in classroom instructions, laboratory activities and research. It was conceived that student's involvement in research and science projects stimulate the high ability students to continue their education and plan for careers in Science and Engineering. Each student was encouraged to select a topic in the fields of Science or Computer Science which involved one of the followings:
A. Laboratory research work; requiring skills to use simple scientific tools and chemicals under laboratory conditions
B. Literature research on any of the modern topics of scientific interest such as laser and fusion, Super conductivity, threat of aid etc.
C. Fabricated Science project which can demonstrate Science Technology applications.
D. Computer simulation/software modifications etc.

This idea of student's involvement in research was a great success. Every student prepared material (see enclosure 4) of his or her choice and presented it to the audiance which included students and faculty. These seminars were jointly chaired by a student and a faculty member. The student chairperson was given the responsibility to introduce the speaker who provided autobiographic material to the chairperson (see enclosure 5\&6). It is intended to put the biographical material of each student, after some minor editing, into a binder for permanent record which would/be kept in the office of the Director of the Project. . If it can be arranged, the project Director will supply a copy of this binder to each participant. Based on the scientific presentation by each participant the SSETP Faculty and Staff selected the following persons for acheivement awards. 
Name

Mr. Victor Mattison

Miss Tonya V. Simmons

Mr. Ernest Pauley

Mr. Ridgo Ridges

Miss Audrey Prince

Mr. Bryant Ownes

Miss Erica Brooks
Topic

Field

First Place

Laser Fusion

Short Software

Second Place

Neutralizing

Power of Anti Acids

Computer Archetect

Third Place

Super Conductivity

Type of chemical reations
Physics

Computer Science

Chemistry

Computer Science

Physics

Chemistry

The caliber of material and its presentation was excellent considering the academic background of each participant. Each winner listed above was awarded an achievement certificate (see enclosure 7) and a cashier's check of $\$ 20.00$ for first place, $\$ 15.00$ for second place and $\$ 10.00$ for the third place. These awards and certificates were awarded by the President of the college on July 22,1988 at the closing banquet (see enclosure 8). The parents of the participants were invited for the banquet. The closing banquet was taped. The video tape is available in the Office of the Director. Dr. McNealey, Vice President of the College high-lighted the occasion by his humerous talk which brought out the role of minority scientists in keeping America ahead of competition . Each participant received a certificate for having successfully completed the SSETP (see enclosure 9). Additionally each particpant received 7 Semeter Hours of academic credit 4, SH in Chemistry and $3 \mathrm{SH}$ in Computer Science - which is transferable to an undergraduate institution of their choice.

Instruction on the use of the library, correction of fundamental deficiencies in Mathematics and Science, discussion on career in Science, 
and the preparation and presentation of papers on the research projects were integral part of this project.

A work assignment sheet is provided here (see enclosure 10). Provision was made for tutoring by undergraduate Chemistry and Computer Science student assistants, in supervised study sessions, and for generous time allotment to teachers for office conferences with students. Supervised study sessions were scheduled for the afternoon hours. Miss LaTonya McFadden, a Senior Chemistry Minor and Mr. Rodney James, a Computer Science Major (B.S. 1988) were employed as laboratory assistants. They performed tutorial services and were constant companions of the SSETP particpants.

\section{Guest Speaker}

Several activities such as project meetings, sessions with the guest speakers, presentation of science application videos and sound filmstrips were scheduled in the afternoon. The guest speakers were drawn from a spectrum of persons, with good scientific as well as community service backgrounds. The speakers who participated in this program represented academia, Claflin College, South Carolina State College, Industry-Ethyl Chemical Corporation, Dupont, Business World and Governmental agencies-Department of Energy. The speakers acted as role models and assisted the participants to examine career choices in Physical Science, Computer Science, Mathematics and Engineering. Selected sound strips and videos which contributed to student's knowledge, were procured from American Chemical Society and National Science Foundation, were screened from time to time. Each such presentation was followed by open discussion in which participants as well as guest speakers took an active part. The guest speaker donated their time and energy free as a service to 
the community. The names of the speakers, their affiliation along with their topics are given below.

1. Earnest McNealey, Ph.D. Vice President Academic Claflin College

2. Bert Knessel, Ph:D Organic Chemist Ethyl Chemical Corporation Orangeburg, S.C. 29115

3: Tony Graham, M.D. Claflin Aluminus Graham Clinic Lake City, S.C. 29560

4. Vernon Middleton Vice President for Alumini Affairs

5. Willie Frazier, Ph.D. Claflin Aluminus Dupont, SRP, Aiken, S.C.

6. James Arrington, Ph.D. Zoologist, Dean College of Science S.C. State College Orangeburg, S.C.

7. George Lee, Director Admissions and Records Claflin College

8. Earl Middleton Claflin Aluminus Owner Operator Coldwell Banker Real Estate Orangeburg, S.C.

9. Frank Wright

HBCU Coordinator

DOE, SRP

Aiken, S.C.
"Future of Minority Scientists"

"Chemistry and You"

"What it takes to Succeed"

"Role of Claflin in our Community"

"SRP and Our Community"

"Bioengineering, Gene Splicing and Human Race."

"Claflin is Good for You?"

"I made it, Can You" 


\section{VI, Industrial/ Academic Visits}

To expose the students to science outside the program and to familiarize them with research tools in science, students were taken to a day-long field trips to scientific laboratories located at places such as the Savannah River Plant (D.O.E. facility in Aiken) and the Medical University of South Carolina in Charleston.

To further expose the students to different scientific settings and provide, appropriate role models, a series of science laboratory visitations and field trips were planned. For example, students visited the University of South Carolina, Columbia, which has regional Nuclear Magnetic Resonance (NMR) facilities and recently completed an engineering center and Savannah River Ecology Laboratory which houses live aligators and many other reptiles. At SRP, students also visited laboratory facilities where research relating to the handling and disposal of radio active waste material is being conducted. The students also visited robots research center at SRP. A number of get together opportunities were made available to the students through picnics and formal dinners. Summer program for participating students was conducted in such a way that students left the campus, at the close of the semester, thinking that Science is fun and a rewarding field to get into. The places visited by participants along their importance are given below:

Place

1. Ethyl Chemical Speciality Chemicals Orangeburg, S.C.

2. Carolina Eastman Columbia/St. Mathews

3. University of South Carolina Columbia, S.C.
Importance

Iboprofin, Alkyl Aluminum and and several pesticide intermediates

Fiber material, Coke, Pepsi Plastic containers etc.

Super Computer Center, Science facilites Engineering Center Campus Tour 
4. Westvaco

Charleston, S.C.

5. Medical University

of South Carolina

Charleston, S.C.

6. Savannah River Plant

Aiken, S.C.

7. Riverbank Zoo

Columbia, S.C.
Paper and Pulp Manufactoring faculty

Department of Anatomy, Pathology

Medcine, Biochemistry, Minority

Center, Campus Tour

Nuclear Power Plant, Nuclear

Waste disposal facilites SRL

and SRE, General Tour of Plant

Visit to Animal Shelter Place etc.

In addition to Scientific and industrially related trips, students participanted in several picnics at places such as Edisto gardens, Battery, Charleston; Capital, Columbia and had lunch in the SRP cafeteria. They also had BBQ at the president's resident and at Dr. Tony Graham's ranch, Lake City, S.C.

The Computer Science Program was supported by a computer laboratory, housing an interactive, time sharing, mini-computer system. The Computer Laboratory is located on the first floor of the air conditioned Science Center. The college owns a Digital Equipment Corporation VAX11/750 RA81/TU80 computer system with $2 \mathrm{MB}$ of ECC MOS memory and 456 MB of disk storage. The laboratory, a "user oriented" computer facility, has 9 VT 220's and 2 VT 240 's (graphic) video terminals. The CRT terminal users were able to get hard copies from the LP 25 line printer.

The Chemistry Department is located on the third floor of the JST Science Center. The equipment in chemistry and the facilities in which it is housed are modern and more than sufficient for instructions at the college level (Professional B.S. in Chemistry). Claflin's Chemistry Department is particularly well positioned for this kind of project, in part, because it has received, since 1972 , several research grants from the Environmental Protection Agency, the United States Department of 
Agriculture and the Department of Energy. The Department owns or has free access to a wide variety of scientific tools and equipment.

\section{The Chemistry Program}

The chemistry program was designed and implemented by D.r. Phillip Schapiro. In addition to the previously mentioned general science objectives, the chemistry program had the following additional objectives.

A. Develop in students the basic knowledge and skills essential to the understanding of chemistry.

B. Develop skills of accuracy and precision in thinking, communication, experimental observation and manipulation

C. Develop an ability to interpret the properties and reaction of atoms and molecules in terms of structural theories.

D. Inspire in each student an interest in Chemistry as an exciting and useful descipline.

E. Guide Students to understand the elementary methods employed to conduct research in the area of Chemistry

In addition to recitations and discussions, in a relaxed classroom environment about the theoretical aspects of chemistry, students were led to perform laboratory work which enabled them to intuitively accept various chemical principles. They were encouraged to select research topics appropriate at their levels for conducting group or individual research. The activities of the chemistry program was organized as outlined below.

First Week. Students were exposed to some physical measurements, periodic table, atoms and molecules, followed by laboratory experiments relating to the theoretical aspects of these discussions. The students were exposed to chemical literature research and encouraged to select topics of their choice for group or individual research. The role and importance of chemical discipline for man and his environment were brought to their attention. Emphasis was placed upon the job and career opportunities which exist in this field. 
Second Week. The students were led into the secret of chemical bonding, formulas equations, and classes of compounds. Laboratory was designed to reinforce the theoretical experience gained by them in the classroom. The students were encouraged to discuss with the instructor the topics of their choice for research for the final selection and approval of one of the research topics for further study.

Third Week. The students were exposed to the mole, energy, and weight relationship. The laboratory work was designed to calculate molarity, normality, equivalent weight, and prepare standard solutions of various acids, and bases. The students designed and set up experiments to meet their respective research objectives pertaining to their selected. research projects and started collecting data or fabricating science projects.

Fourth Week. During this week students studied acids, bases, and salts. Theoretical aspects of proton donor and its relation to $\mathrm{pH}$ were discussed. The laboratory work was designed to determine the acidity of lemon juice, vinegar, and acid neutralizing power of various anti-acids available in the market. The student continued to work on their projects collecting data.

Fifth Week. The students were exposed to the gas laws, and the kinetic-theory of gases. Laboratory work was designed to study the diffusion and weight relations of gases, relations of pressure temperature, and volume were explored. Students fabricated their own equipment for these experiments. The students continued to collect research data and prepared manuscripts for seminars.

Sixth Week.: Final test was held. Research/Science Projects were written up for presentation at the seminars. Seminars were held (see enclosure 5). The Research and Science Project data were presented. Students evaluated the SSETP project (see enclosure 11). 


\section{The Computer Science Program}

The Computer Science Program was designed and implemented by Mr. Eges Egedigwe, Director of Computer Lab. Upon completing of the Computer Science Program, we expected the students to analyze simple scientific/mathematical type problems, to write BASIC programs for solving them numerically, to enter the programs on the computer, to correct the errors, and to execute them properly on the College computer system. The students were able to:

1. Analyze simple science/mathematics problems and to devise algorithms for solving them.

2. Express the algorithms in sequence of computer steps.

3. Code the steps in the BASIC language.

4. Enter the computer code into the computer system, edit the code, list the code, and execute the code.

5. Modify existing programs in order to meet a modified statement of the initital problem.

6. Use available software/methodology of C.S. for learning Chemical facts.

7. Application of computer for learning Chemistry.

8. Modify existing programs in order to improve them structuraly, and to make them clear, faster, and efficient.

9. Use computer jargon and concepts properly

10. Apply computer methods in fields like, sorting simulation gaming, word-processing, mathematics, economics engineering and the other science fields.

\section{Evaluation}

Each student's performance was quantitatively evaluated through objectives type of testing procedure which was adopted by each participating instructor. Three tests, including the final two hour tests, were given in 
each area to evaluate the learning potential of each student and his or her ability to perform in Science, Mathematics, and Engineering fields.

Each instructor also performed a qualitative analysis on each participant to evaluate his or her motivation, energy, and desire to succeed in their chosen academic field through intelligent particpation and hard work. All participants with one exception were absolutely positive to select careers in Science, Engineering and Computer Science. No student took advantage of the facilities available at Claflin College to prepare for SAT etc. There were several reasons for this as given below.
A. The normal project load was so heavy that the participants could not spare time to put in this direction.
B. Over $30 \%$ of students had already taken their SAT and were accepted for undergraduate studies in the college of their choice.
C. Students and faculty got keenly absorbed in research; consequently could not divert resources for SAT Preparation.

Three of six students selected in this program from the College's freshmen class decided to stay with the Department of Chemistry or Computer Science.

The data generated by each instructor is being compiled by the program director for an overall evaluation of each participant. This could not be done in the sixth week due to lack of time and coordination as instructors were busy. Each participant was awarded a certificate at the closing ceremony, which was held on July 22,1988 , the last day of work at Claflin College. The parents and the college administrators joined this occasion. The final banquet was well attended and was taped for future reference.

The course outlines in Chemistry and Computer Science Programs offered, during the summer sessions at Claflin College have been supplied to participating schools, Department of Chemistry and Department of 
Computer Science at Claflin College, with the recommendation that each participant be awarded 4 Semester Hour credit in Chemistry and 3 Semester Hour credit in Computer Science.

\section{Follow Up}

Each participant at some future date will be provided with his or her confidential rating report and analysis of his or her future goals. The Director has designed and set up a mechanism to establish contacts with the students, for monitoring his or her Science, Engeineering and Computer Science careers.

\section{Pre-College Science Engineering and Mathematics Seminar}

In continuation with our efforts to motivate the high school students, the student Science Enrichment Training program in cooperation with the College administration, held one day Pre-College Engineering, Science and Methmatics Seminar. The summer Science participants and the high school counselors joined a group of other high school students for the seminar. The seminaries was held on December 3,1988 which was also a home coming for Claflin College. Claflin was having a home coming basketball game. The college's Pantherettes (lady basketball team) ended their season with a number two spot in the NATION. Several activities were scheduled for the visitors. However; the major theme was to bring to the attention of visitors what Claflin could do for them in the field of undergraduate science and computer studies. The visitors were Claflin guests and were allowed free to get in the basketball game. All the visitors were introduced during the half time.

Monitoring of student progress will continue through out his or her college life to collect data to evaluate the degree of success of the project. The monitoring of students progress and his ultimate success will continue beyond the project period of summer 1990 , even though no federal funds 
will be available at that time. College agreed to allocate resources to achieve this part of the project objectives. The college feels strongly about the validity and the usefulness of this project. Consequently it decided to commit its resources to accept the responsibilities of bringing the project to successful completion and probably develop a model for use nation wide by other schools and colleges.

\section{Organization and Management}

The project was initiated on June 13,1988 to coincide with the College Summer' School 1988. Its duration was six weeks. Dr. S.S. Sandhu carried the primary responsibility for the operation of the project. A SSETP Advisory Committee consisting of Dr. Schapiro, Mr. Egedigwe, Ms. McFadden and Mr. James was established. Dr. Sandhu served as a chairman of this committee. An abbreviated Curriculum Vita for each instructor appeared under staff. Selection of participants was done by the SSETP faculty and staff.

The project instructors had a few days, prior to starting date, for the preparation of instructional materials for finalizing their plan of action for class, laboratory, research, and program activities.

The College General Fee allowed the participants to become involved in the athletic and social recreational programs, organized by the College. Nevertheless, two laboratory assistants were employed to serve (1) as coordinators of recreational programs (2) to coordinate the tutoring in supervised environment and (3) to help in Chemistry and Computer laboratories. The Project Director's responsibilites also included the organization of student activities and visitation by the guest speakers.

The formal evaluation of the project programs was done first by students on end-of-semester evaluation forms. Secondly, by student laboratory assistants and finally, during the final week, the project 
instructors participated in the evaluation of project activities. The instructors met to share the experiences and evaluate the project from their prospectives. The Project Director is presently in the processes of consolidating this information.

\section{Staff}

There were several deviations in faculty hiring as compared to the one outlined in the orginal project proposal Mrs. Cinthia Boatwright did not accept contract to work for the College during 1988-89 school years. College administration ordered Project Director not to offer her teaching position in the SSETP project. She was replaced by Mr. Eges N. Egedigwe, Director of Computer Laboratory at Claflin College.

Dr. Todd Hizer accepted a summer research position with the Department of Chemistry, University of South Carolina, Columbia, SC. Consequently he was replaced by Dr. Phillip Joseph Schapiro, Associated Professor, Division of Science and Mathematics and Computer Science. In addition to these two instructors, the project employed two laboratory asssistants namely Miss LaTonya McFadden and Mr. Rodney James. The abbreviated curriculum vita for each project participant is given below:

Dr. Shingara S. Sandhu, Project Director

Dr. Sandhu was born in Punjab, India on October 10, 1932. He received his M.S. in Chemistry from Punjab University, Chandigarh in 1954, and his Ph.D. in Environmental Chemistry from Utah State University 1970.

His post-doctoral studies and training include: Environmental application of $\mathrm{GC} / \mathrm{mass}$ spectrometry; water resources training; Nuclear Magnetic Resonance Spectroscopy; speciation of metal ions in Aquatic System and Sluice; computer application in undergraduate chemistry programs; environmental assessment program; Thermodynamics of 
Water and Heat Fluxes, and instrumental application in Chemistry. His research has related to Recondite Toxicity of Arsenic Species, Kinetics of Degradation and Transport of Pollutants in Human Environment, Methods Development for Total Arsenic and Arsenic Speciation in Biological and Aquatic Systems. His research has been in the Environmental Analytical and Environmental Physical Chemistry.

Dr. Sandhu has taught College Chemistry, including Physical Chemistry and Instrumental methods of Chemical Analysis, since 1955. At present, in addition to teaching, he is principal investigator for the project funded by Department of Energy. He has over 40 publications. He is a member of American Chemical Society and its Environmental Divisions. Dr. Phillip Joseph Schapiro; Chemistry Instructor

Dr. Schapiro receieved his Ph.D. degree in Physical Chemistry from Ithaca, N.Y., in 1960. He specialized in x-ray determination of crystal structures. He also received his Ph.D. degree in Mathematics from Oklahoma University in 1976 and specialized in Topology.

He held several teaching positions in colleges and Universities such as University of South Carolina, Aiken; Paine College, Augusta, and Oklahoma University and presently is employed by Claflin College, Orangeburg, S.C. as Associate Professor, Division of Natural Science and Mathematics and Computer Science. He has authored several scholarly publications and is active in many learned societies like American Chemical Society, American Mathematical Society, Phi Beta Kappa and Sigma XI.

Mr. Eges N. Egedigwe; Computer Science Instructor

Born and raised in Nigeria he received his B.S. degree in 1980 from University of IFE, Nigeria. He received his second master in Computer Science 1986 and first master in Finance/Accounting 1984, from Atlanta 
University, Ga. Since completing his education he has worked in several capacties such as data Analyst, System Consultant and processing consultant in private corporation and Univiersity settings. He was employed by Claflin College in 1986 as Director of Computer Center.

Here at Claflin his responsibilites include management and control of VAS/VMS-11/750: development and implementation of the computer information system, memory managment; system consultant, software maintainance and installation; maintaining user account; creating modular library procedures, system security and updates, backup; and supervision of operators of the system.

In addition to computer suprvisory role he also teaches such courses as Basic, Cobol, Fortran, Pascal, Assembly Language, Computer Concepts, Numerical Aanalysis, Linear Programming and Operation Research. $\mathrm{He}$ is very energetic and likeable young teacher.

\section{Miss LaTonya F. McFadden; Chemistry Lab Instructor/Tutor}

Miss McFadden was born and raised in South Carolina. She is presently Senior at Claflin College, minoring in Chemistry and majoring in Biology. She is an honor role student at Claflin College. She has acquired many professional skills relating to the medical profession, teaching computer and chemistry by working for Graham's Medical Clinic and and tutoring for the Special Services at Claflin College. She attended several academically orientated institutes, in place like Fisk Univerisity, Benedict College and Williamsburg's Technical College.

She is a member of Who's Who Among American Colleges and Universities, Alpha Kappa Mu National Honor Society and Claflin College Pre-Alumini Council.

Mr. Rodney A. James; Computer Instructor/ Tutor 
Mr. James was born and raised in South Carolina and received his B.S. degree in Computer Science and Mathematics from Claflin College in June 1988. He worked as a computer Laboratory Assistant at Claflin College during his tenure as a student.

In his capacity as Laboratory Assistant he tutored the students in Mathemicatic and Computer Science, wrote and debugged systems and monitored the computer laboratory for courses in Basic, Fortran, Pascal , Cobol and File Processing.

\section{Benefit of SSETP}

\section{A. Motivational:}

Upon completion of this program all of the participants were motivated to enroll in high school science and mathematics courses, and hopefully will work hard to prepare themselves for college entrance. All participants except one who chose to follow the profession of law, was eager, to pursue careers in Science, Engineering, Computer and Mathematics as he or she goes to the college of their choice. Claflin students who chose to participate in this program, were urged to continue their career in Chemistry and Computer Science. Indeed, during the Fall Semester of 1988, the Project Director will try to invite school principals or their designees to estimate the general effect of the project on the pariticipants, and their subsequent classrooms performance.

\section{B. Claflin College as Beneficiary}

Availability of funds for summer academic programs in Chemistry were great attraction and inducement for 1987-88 freshmen class at Claflin College to opt for Chemistry career. Minority teens, especially of rural areas, have a very difficult time in getting rewarding summer jobs. The college, having received funding through this project, contributed richly to the professional growth of the student throughout his or her stay in the 
college. The added attraction of academic summer program in Chemistry along with the growing demand for Science and Engineering professional probably will contribute towards increased enrollment in the Department of Chemistry at Claflin College. Two students out of seven who participated in SSETP from Claflin College changed their major to Chemistry. It is a good beginning.

\section{Academic Head Start:}

The participants had a head start over the general high school population who intend to go to college. They have also favorable and promising start. Not only they earned 7 Semester Hours of credit-4 SH in Chemistry and $3 \mathrm{SH}$ in Computer Science-to carry to the college of their choice they also had an early taste of college life; the freedom and the responsibilities that follow such activites. They were able to see first hand the Chemists, the Computer Scientists, Physicist/s and Physicians in action. They saw the role of Chemistry in Human Life. 


\section{STUDENT SCIENCE ENRICHMENT TRAINING PROGRAM INFORMATION DISSEMINATION}

SSETP Brochure was published. It provided information to the potential participants about the requirement for entering the SSETP program and their obligations. The brochures were mailed to the Science Teacher of every high school in the State of South Carolina which was followed by telephone calls to some schools, which are located in rural areas away from cosmopolitan cities. Every student of the freshmen class of 1987-88 at Claflin College was provided with SSETP brochure. Additionally, every orientation teacher of the freshman class was requested to spend sometime in his or her class to provide information to the students about the SSETP.

A few days prior to the initiation of the SSETP at Claflin College the Director of the Program was invited by the Jones Inter Cable TV, Orangeburg, S.C. for in depth discussion of the requirements and future impact of SSETP on Science and Engineering fields. The tape of this recording is available in the office of the Project Director. The taped program was screened for the TV viewing audiance in South Carolina.

A reporter from Times and Democrat, a popular local daily news paper; visited the college for an interview with the Director and to observe the SSETP students in operation. The reporter wrote an article which not only was complimentary to the program but also provided an in depth analysis of the program. The interviews with the various news media were arranged by the college Public Relation officer, Mrs. Lemon. A representative of Quicky Radio Station, St. Mathews, also visited the college to observe the SSETP participants in action. The Times and Democrat reporter also participated in the closing day ceremonies of the SSETP which 
was high lighted by a banquet, award of certificates and achievement awards. The Jones Inter Cable TV invited the students and the Project director for an interview on July 25, 1988. The taped interview was screened for the viewing audiance in South Carolina. A copy of the taped interview is kept in the Office of the Director, the final day banquet and the award cermonies were taped for future reference.

\section{PROPOSEU SCHEDULE OF ACITIVITES}

\section{FY 1989-90}

Description of the project activitites was detailed in the orginal project proposal which was submitted to the Department of Energy in the Spring of 1988. Major activities for Fall of 1988 related to the follow up studies of the academic achievements of the participants. The Director has established a mechanism to contact the students and their academic counselors. A report on the quantitative and qualilative evaluation of his or her motivation, energy and desire to succeed in their chosen academic field will be mailed to each SSETP graduate in due course of time. The director will continue to maintain close ties and contacts with the SSETP graduates through telephone calls and other contacts. He will coordinate his activites through respective academic couselors who will help the students to make career choices.

The brochure providing information to the potential participants has been published for 1989 summer program. Five copies of the brochure have been provided to the office of the Academic Counselor of each high school. The counselors along with the science teachers have been urged to identify such students who have potential to go into Science and Engineering fields and have such students to apply for the SSETP program during 1989 
summer to be held at the campus. The 1988-89 freshmen class at Claflin College has been provided with the copies of the SSETP brochure. The attempt will be made to mail a copy of the brochure to the parents of the freshman class of 1988-89. The parental help will be solicited to see if the students can be urged to select careers in Science, Engineering and Mathematics. It is also desired to provide copies of the brochure to the SSETP participants of 1988 summer, for them to identify students in their schools who may be interested in participating in SSETP.

A merit list of applicants based on the information supplied by the potential participants will be prepared by the Director. The top 30 applicants will be offered spots in the SSETP, for them either to accept or reject the offer by April 29, 1989. A subsequent list of candidates will be prepared and additional potential participants will be contacted in case a need arises.

The project will be inititated June 12, 1989 to coincide with the College Summer School of 1989. Its duration will be six weeks. Dr. Phillip Schapiro and Mr. Eges Egedigwe will serve as Chemistry and Computer Science instructors respectively. One student will be hired as laboratory assistant and tutor and to manage the out of class activities, such as local trips, picnics, visitations to various points of interests within the State of South Carolina. Introduction and class registration for courses will be done on the first day of the school. The abbreviated curriculum vita for each of the project instructors appears under the progress reports of SSETP for the year 1988-1989. The SSETP will run through July 21, 1989.

The activities listed in the orginal project were found appropriate and rewarding for the target audiance and will be repeated for 1989 SSETP, with one exception that we would like to invite the SSETP Alumini for the final 
banquet which will be held on the last day of 1989 summer. Each SSETP Aluminus who will come to participate in the banquet to be held at Claflin College campus must be compensated for travel cost. The project must also provide lunch to the alumini at the banquet.

It is also conceived desirable and benefical for future contacts to invite the High School Principals or their designees to attend the 1989 closing Banquet. We would like to have the schools get deeply involved in the future of Science in the United States of America. The school representative who will decide to come must be compensated for travel and lunch. 